Jpn. J. Hosp. Pharm.

$\left[\begin{array}{c}\text { 资 } \\ 20 \text { (6) } 556-559(1994)^{2}\end{array}\right]$

\title{
坐剂の使用に関する幼児および小児の母親の意識調查と問題点の解析 $\dagger^{1}$
}

山下佳子 $\dagger^{2}$, 小滝 $-\dagger^{2}$, 田中嘉一 $\dagger^{2}$, 山田安彦 $\dagger^{2}$, 中村幸一 $\dagger^{2}$,

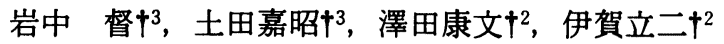

東京大学医学部附属病院薬荗部 +2 , 同小児外科 $t^{3}$

\section{Survey on Use of Suppositories in Mothers of Infant and Child Patients and Analysis of Problematic Use ${ }^{1}$}

\author{
Yoshiko Yamashita $\dagger^{2}$, Hajime Kotaki $\dagger^{2}$, YoshikazU Tanaka ${ }^{2}$, \\ YASUHIKO YAMADA $\dagger^{2}$, KOUICHI NAKAMURA $\dagger^{2}$, TADASHI IWANAKA $\dagger^{3}$, \\ YOSHIAKI TSUCHIDA $\dagger^{3}$, YASUfUMI SAWADA $\dagger^{2}$ and TATSUJI IgA $\dagger^{2}$ \\ Department of Pharmacy, University of Tokyo Hospital, Faculty of \\ Medicine, University of Tokyo ${ }^{2}$, Department of Pediatric Surgery ${ }^{3}$
}

$\left(\begin{array}{ll}\text { Received June 20, } & 1994 \\ \text { Accepted July 29, } & 1994\end{array}\right)$

\begin{abstract}
When suppositories were prescribed for pediatric patients, they are inserted into the rectum of the patient by the mother in most cases. Therefore, counselling on the proper use of suppositories is essential. In an attempt to facilitate counselling for drug use, we surveyed via questionnaire how the mothers (ranging 26-39 years) of pediatric inpatients (2.5 months-15 years) of the University of Tokyo Hospital use suppositories. The collection ratio of the questionnaire was $100 \%$ ( 42 of 42 ). The suppositories exhibiting a systemic action such as antipyretic were used in $80 \%$ of patients. The directions for use of suppositories were not well appreciated in $15 \%$ of mothers. Twenty percent of mothers experienced trouble when inserting the suppositories into their children, and $54 \%$ of the trouble was "discharge after insertion of the suppository". Most of this discharge occurred within 30 minutes after insertion. When the discharge occurred with a stool, $64 \%$ of the mothers coped with the trouble as "suspended the use of the suppository" and $36 \%$ as "inserted a new one", and so on. Our results indicate that the study dealing with the problem of the loss of suppositories from the rectum is essential for the proper therapy of patients.
\end{abstract}

Keywords—- survey, suppository, discharge, pediatric patients, mother

はじめに

薬剤師が患者に対して適切な服薬指導を行らた

$\dagger^{1}$ 本論文の一部は日本 薬 学 会 第 114 年会（東京, 1994年 3 月）で発表.

†2,3 東京都文京区本郷 7-3-1；7-3-1, Hongo, Bunkyo-ku, Tokyo, 113 Japan
めには，科学的根拠に基づいた多くの薬品情報を 収集し，患者にわかりやすく情報を提供する必要 がある．特に坐剤の服薬指導の場合，どの程度の 時間坐剤を肛門内に拌入しておけばよいのか,そ して坐剤の途中排出が起こった場合にどのように 対処すればよいのか等の情報提供は，薬物治療上 きわめて重要な事柄である．我々は坐剤の必要挿 
入時間について, 薬物動態論的解析に基ついて定 量的な説明が可能であることを報告しだ1).さら に成人患者を対象とした実態調査において，坐剤 挿入時に困ったことのある患者の約半数が途中排 出に関するものであったことを報告している2).

このことは, 患者への坐剤の適切な使用説明を行 らためには, 途中排出時の対処法などを十分に考 慮して情報提供を行ら必要があることを示してい る.

一方，幼児および小児に坐剤を使用する場合， 介護者である母親が挿入するケースが多いと考え られる.したがって，これらの患者に拈ける坐剤 の適切な使用説明は, その母親に対して行うこと が必要である．そのためには，坐剤の使用に関す る母親の意識と使用実態を把握することが必須で ある.そこで，幼児および小児に坐剤を使用して いる母親を対象に，坐剂に関する意識調査を行 い,その問題点について解析を行った。

\section{方法}

\section{1. 調查対象}

東京大学病院の小児外科入院患者の母親 42 名を 対象に, 平成 5 年10月から平成 5 年12月までの 3 カ月間にアンヶート調查を行った。

\section{2. 調查項目}

アンケートは, 既報2) の外来患者について行っ たものと基本的に同じものを使用した，その内容 は性別, 年龄, 坐剂使用説明書の理解の程度, 坐 剂使用時の手洗い, 保存方法, 坐剂の使用経験の 有無, 坐剂使用時に困ったことなど19項目から構 成されている.

\section{結果}

\section{1. アンケートの回収率と年龄櫵成}

アンケートは患者の母親42名全員から回収でき た.母親の平均年龄は32歳（範囲：26〜39歳）で あり，小児患者の年龄構成は, 2.5 力 15歳の 範囲にわたって分布しており，1３歳の患者が 45\%\%を占めていた（図 1 ）.

\section{2. 坐靔の使用目的}

「お子さんは病院でどのような目的で坐薬をも

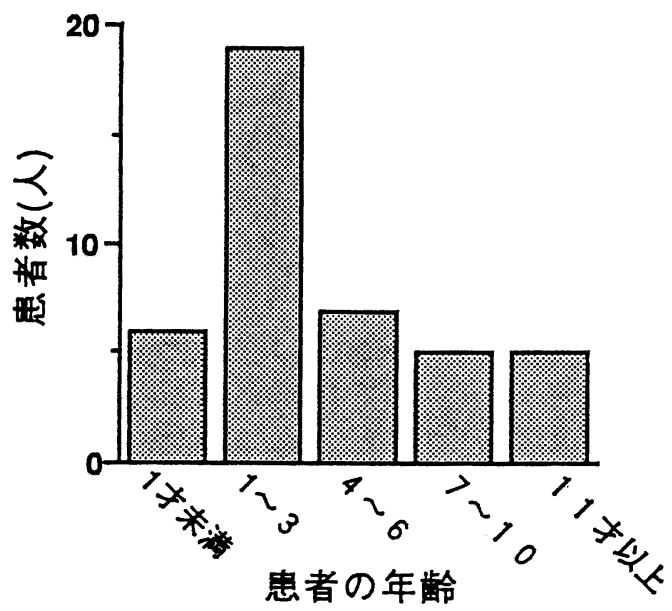

因 1. 小児外科入院患者における年龄構成

らいましたか」という質問に対しては，「全身作 用を目的とした坐剤を使用していた」と回答した 母親が93\%であり，その大部分 $(98 \%)$ はアンヒ バ坐剤（アセトアミノフェン含有）であった.

\section{3. 坐剂の使用鮵明書の理解度}

坐剂に同封されている説明書の理解の程度に関 する回答結果を図 2 にまとめた。説明書が不要と 答えた母親とよく理解できたと答えた母親を合計 した割合は $81 \%$ \%゙った，一方，理解しにくいと 答えた母親も16\%程度いることがわかった．母親 自身の坐剤の使用経験回数は $1 \sim 5$ 回が半数近く 占めており，また 30 回以上と多い母親は $27 \%$ 、 た. 図 2 に拉いて説明書が理解しにくいと答えた 母親はすべて使用経験が 5 回以下であり, 説明書 は不要と答えたのは使用経験が30回以上の母親で あった。

\section{4. 坐猎㨂入の仕方と捅入前後の手洗い}

坐剂を使用するとき，坐剂を直接手に持って挿 入していた母親は71\%であった，直接手に持たな いと回答した母親は、ティッシュペーパーあるい は挿入補助紙を使用して挿入していた．眓 3 に示 す坐剂の使用前後の手洗いに関しては，「使用す る前と使用した後のいずれも手を洗う」と回答し た母親が最も多く, 半数近くを占めていた。一 方，全く手を洗わない母親も4\%いた.

\section{5. 坐唷㨉入時の問題}

坐剂挿入時に困ったことの内容：「困ったこと 


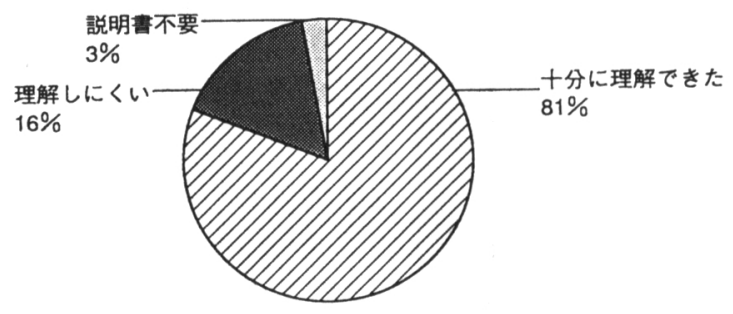

図 2. 坐剂説明書の内容についての母親の理解度

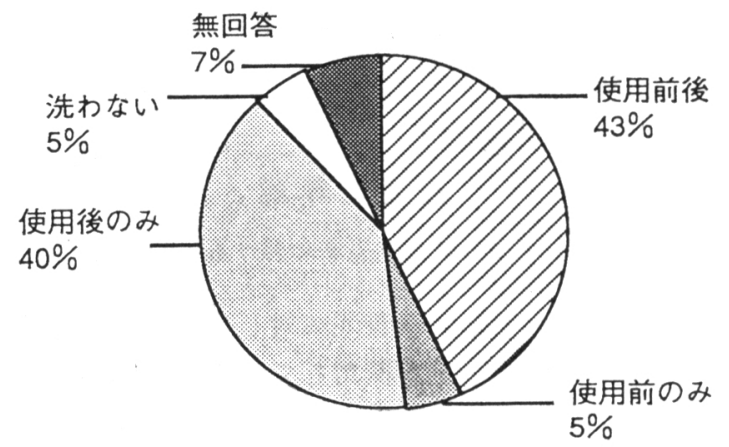

図 3. 坐剂の插入前後の手洗いについての 調査結果

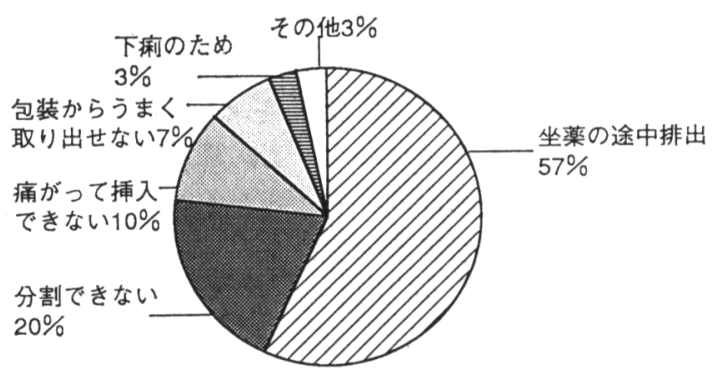

成 4. 坐剂使用において母親が困った ことのある内容とその割合

がある」と回答した母親は $20 \%$ \%た。「困ったこ とがある」と答えた内容で最も多かった理由は,

「挿入後に坐剂が出てしまった」という回答で,

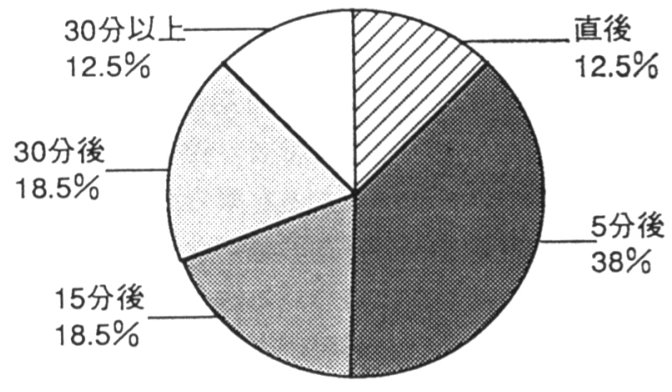

図 5. 坐剂を挿入してから途中排出が起こる までの時間

半数以上を占めていた，次に多かった理由は「坐 剂を半分に分割できない」「子供が痛がって拽入 できない」などであった（図4）。

\section{6. 坐剤の途中排出についての母親の対処}

表 1 に坐剂が途中排出したとき，母親がどのよ らな対処を行ったかについて, 既報 ${ }^{2)} の$ 外来患者 の場合と比較してまとめた．坐剂の途中排出が排 便によって起こった場合，64\%の母親が坐剤の使 用を中止していた。36\%の母親が「新しい坐剂を 挿入した」と回答した。一方, 坐剂のみが排出し た場合の対処法として，逆に「排出した坐剤を再 び挿入した」と回答した母親が多かった。外来患 者の場合と比較して，その対処法が顕著に異なっ ていたのは，小児患者の母親の場合には，いずれ の排出状態においても使用を中止する割合が明ら かに高いことであった，図 5 に示す「坐剂の途中 排出が插入後どの位の時間経過して起こりました か」といら質問に対しては, 坐剂挿入 5 分後に排 出が起こった場合が $38 \%$ と最も多かった以外は, 插入後の時間による排出率に大きな差は見られな かった. 途中排出は插入後30分以内に大部分起こ っていた.

表 1. 坐剂が途中排出した場合の対処方法

\begin{tabular}{|c|c|c|c|c|}
\hline \multirow[b]{2}{*}{ 対処方法 } & \multicolumn{2}{|c|}{ 小児外科入院患者の母親(\%) } & \multicolumn{2}{|c|}{ 外来患者 $(\%) n=67$} \\
\hline & $\begin{array}{l}\text { 排便と } \\
\text { 共に排出 }\end{array}$ & $\begin{array}{c}\text { 坐薬のみ } \\
\text { 排出 }\end{array}$ & $\begin{array}{l}\text { 排便と } \\
\text { 共に排出 }\end{array}$ & $\begin{array}{c}\text { 坐薬のみ } \\
\text { 排出 }\end{array}$ \\
\hline 使用を中止した & 64 & 33 & 14 & 4 \\
\hline 排出した坐薬を再挿入 & 0 & 61 & 10 & 66 \\
\hline 新しい坐薬を挿入 & 36 & 6 & 57 & 30 \\
\hline 無回答 & 0 & 0 & 19 & 0 \\
\hline
\end{tabular}

外来患者のデータは文献 2 ）より引用. 


\section{考察}

本研究では，坐剂に関する適切な使用説明を患 者に行らことを目的に，母親が子供に坐剤を使用 する場合，実際にどのようなことで困っているの か，どの程度の患者が途中排出を経験しているの か，またその場合にどのように対処しているのか などの実態について明らかにし，それらの問題点 について解析した.

坐斉の挿入法, 挿入前後の手洗い, および坐剂 の使用説明の理解度については，外来患者の場 合 ${ }^{2)}$ 同様であった。すなわち，外来患者の場合 「坐珴を直接手に持って挿入」が60\%，手洗いに 関しては「使用前後のいずれも手を洗う」が50\% および説明書の理解度に関しては「内容を十分に 理解できた」が76\%である。

坐剂の使用説明書が理解しにくいと答えた母親 が16\%程度存在したが，これらの母親はすべて本 人自身の坐剂使用経験が 5 回以下であった．この ことは坐剂の使用経験の少ない母親に対して坐剂 のより適切な使用説明が必要であることを示唆し ている. 坐剤が途中排出した場 合, 血中濃度が 排出した時間によって急激に変化することにな $\eta^{1,3)}$ ，全身作用を目的とした坐剂では結果的に十 分な治療効果が得られない眯念がある．本調査に おいて，坐剂の途中排出を経験している母親が成 人の外来患者と同様に多数いること，またその途 中排出の大部分は插入後30分以内に起こっている ことがわかった。この情報は，今後途中排出に関
する適切な対処法を動物実験3)および臨床試験に よって検討することが有用であると考える.

途中排出が起こった場合，排便と同時に起こっ たのかどらかで母親の対処が異なることが示唆さ れた（表 1 ）．しかし，その場合の対処について成 人の外来患者と比較すると，その小児患者の母親 の場合には，排便の有無に関わらず途中排出時に は投与を中止すると答えた割合が多かった。この 要因として，排便と共に坐剤が排出する場合，小 児では坐剂㨀入による刺激のために容易に排便し てしまうこと，また，坐剤のみが排出する場合， 肛門自体がゆるくなっており，挿入してもすぐに 排出が起こるために，坐阂以外の剂形に変更する ことが多いことが考えられる。

本調査から，幼児拉よび小児へ坐剤を插入して 途中排出を経験している介護者としての母親が， 相当数いることが明らかとなった。ささらに，その 対処法についても様々であることがわかり，途中 排出時の適切な処居法の確立が必須である.

\section{引用文献}

1）山下佳子, 小滝 一, 山田安彦, 中村幸一, 澤田 康文, 伊賀立二, 病院薬学, 19, 184-190(1993).

2）山下佳子, 小滝 一, 渡辺ひさ恵, 山田安彦, 中 村幸一, 澤田康文, 伊賀立二, 病院薬学, 20,8996 (1994).

3）田中嘉一, 小渑一, 中村 均, 内野克喜, 澤田 康文，伊賀立二，病院薬学，20(4)，294-301 (1994). 